\title{
The Power of Language in Adjudication and Mediation: Institutional Contexts as Predictors of Social Evaluation
}

\section{Calvin Morrill and Peter C. Facciola}

The language used by witnesses and litigants can powerfully influence evaluations by legal decision makers of disputant credibility and blame. Previous experimental research has addressed this claim in many studies of undergraduates and law students. It is not known whether this generalization applies to sitting judges or whether it extends to other institutional contexts in which dispute settlement occurs, such as mediation centers. In this article we present findings from three experiments conducted with undergraduates, sitting judges, and practicing mediators. Speech style (powerful powerless) and discourse (rule, relational) were manipulated in a $2 \times 2$ repeated measures design in each subject pool. The findings suggest that students' and judges' evaluations of disputant credibility, social characteristics, and blame are affected by speech style, while mediators' evaluations of the same are affected by particular interactions of speech style and discourse only. These findings are interpreted as a function of the prescriptive and behavioral language norms to which students, judges, and mediators are routinely exposed in their

Calvin Morrill is assistant professor of communication and sociology at the University of Arizona. Peter C. Facciola is a doctoral student in the Department of Language, Reading and Culture in the College of Education at the University of Arizona.

Financial support for this project was provided by the Social and Behavioral Sciences Research Institute at the University of Arizona. Portions of this article were presented at the Law and Society Association meetings in Madison, Wisconsin, in June 1989 and to the Arizona Women Lawyers Association in Tucson in March 1990. The authors greatly appreciate the assistance of officials at the Maricopa County Superior Court, Phoenix Community Mediation, and Tucson Community Mediation, all in Arizona, withour whom this research would have been impossible; and our research assistant, Ellen Snyderman. William Bailey, Albert Bergesen, Donald Black, Michael Burgoon, Sara Cobb, Linda Devoy, Shari Seidman Diamond, Peggy Evans, Neal Fligstein, Craig McEwen, Linda Molm, William O'Barr, Dirk Scheerhorn, David Snow, and Ann Yellot provided invaluable comments during the design, execution, and write-up of the research. 
institutional contexts. Implications for future law and language research are also discussed.

A new field of inquiry into law and language emerged during the past decade. Early linguistic scholarship focused on the evolution and style of written legal language, ${ }^{1}$ while current research on law and language addresses verbal communication during case processing. By drawing attention to verbal communication, researchers have recognized that the study of language-in-use can shed light on the functioning of legal institutions generally and specifically on the sources of disputant success in pursuing their grievances. $^{2}$ Of special interest in this emerging area is the relationship between the language litigants and witnesses use and its social evaluation by legal decision makers. Social evaluations are important, for they may insinuate information about the social and personal characteristics of disputants into proceedings (beyond that contained in the content of testimony), which in turn can affect case outcomes. ${ }^{3}$ Such evaluations may also reveal the role that institutional contexts play in the evaluation of language and disposition of cases by legal decision makers. ${ }^{4}$ This last point fits with findings in sociolinguistic studies of language and social evaluation that all kinds of social contexts can have profound effects on communicatively based perceptions of attributions and social characteristics. ${ }^{5} \mathrm{We}$ seek here to advance knowledge about law and language through a series of experiments carried out with undergraduates and, for the first time in research of this kind, with legal and alternative dispute settlement decision makers: sitting judges and practicing community mediators.

\section{BACKGROUND AND RESEARCH QUESTIONS}

Much of the current work on law and language emanates from seminal investigations by William O'Barr and his associates into the description of "speech styles" in court and their perceptual effects in subsequent experiments. ${ }^{6}$ Although speech styles can vary along several different

1. See, e.g., David Mellinkoff, The Language of the Law (Boston: Little, Brown, 1963; David Crystal \& Derek Davy, Investigating English Style 193-217 (Bloomington: Indiana University Press, 1969).

2. For a recent review of this work in the United States see William M. O'Barr \& John M. Conley, "Litigant Satisfaction versus Legal Adequacy in Small Claims Court Narratives," 19 Law \& Soc'y Rev. 661 (1185).

3. Donald Black, Sociological Justice 18-19 (New York: Oxford University Press, 1989).

4. See O'Barr \& Conley, 19 Law \& Soc'y Rev. 661.

5. See, e.g., Howard Giles \& Peter F. Powesland, Speech Style and Social Evaluation (New York: Academic Press, 1975).

6. For a synthesis of O'Barr's work on speech styles, see William O'Barr, Linguistic Evidence: Language, Power and Strategy in the Courtroom (New York: Academic Press, 1982) ("O'Barr, Linguistic Evidence"). It should also be noted that not all studies of oral communication in courtrooms originate in O'Barr or involve speech style effects. For a review of 
dimensions, O'Barr focused on two styles that form a continuum ranging from "powerful" speech approximated by formal, grammatically correct English, to "powerless" speech that exhibits awkward grammar, word selection, and excess linguistic elements that convolute messages. ${ }^{7}$ In particular, powerless speakers tend to often use intensifiers (such as "surely," "very," "so"- as in "She is so nice"), hedges (such as "sort of," "like," "kinda"- as in "I kinda like math"), hesitations (such as "uh," "um," "you know"-as in "He, uh, you know, could be the fellow"), tag questions (turning declarative sentences into questions with a rising intonation at the end or a questioning phrase, as in "The bus stops here?" or "John's here, isn't he?"), or extreme polite forms (as in "Sir, I can answer the question, thank you").

Recent ethnographies of small claims courts suggest that another important manifestation of language in the courtroom occurs in discourse, reflecting a speaker's orientation toward a case and social status. ${ }^{8}$ Discourse is generally regarded as comprising linguistic elements at the sentence level or larger. ${ }^{9}$ Two types of discourse have been identified: a "rule" oriented testimony in which a speaker focuses on normative violations in a dispute (e.g., the "facts" of the case) and a "relational" testimony that focuses on the social relationships in which a dispute is embedded (e.g., the relationships between the principals and other participants).

anthropological work on language in the disputing process, see David Brenneis, "Language and Disputing," 17 Ann. Rev. Anthropology 221 (1988). For evidence that inflections given to individual words can significantly affect responses to lawyers' questions, see Elizabeth Loftus, Eyewitness Testimony (Cambridge, Mass.: Harvard University Press, 1979); Brenda Danet, "Language and the Legal Process," 14 Law \& Soc'y Rev. 445 (1980). See W. Lance Bennett \& Martha Feldman, Reconstructing Reality in the Courtroom (New Brunswick, N.J.: Rutgers University Press, 1981), who focus on how jurors make sense of different types of testimony "stories." See also the critique in Susan Phillips, "Review of Reconstructing Reality in the Courtroom, by Bennett and Williams," 12 Language in Soc'y 514 (1983). For conversational analysis and ethnomethodological approaches to the study of oral communication in the courtroom, see Anita Pomerantz, "Attributions of Responsibility: Blamings" 12 Sociology 115 (1978); J. Maxwell Atkinson \& Paul Drew, Order in Court: The Organisation of Verbal Interaction in Judicial Settings (London: Macmillan, 1979); Anita Pomerantz \& J. Maxwell Atkinson, "Ethnomethodology, Conversational Analysis, and Study of Courtroom Interaction," in D. J. Muller, D. E. Blackmun, \& A. J. Chapman, eds., Psychology and Law (Chichester, Eng.: Wiley, 1984). For a study of how narrative structures in plea bargaining embed and motivate negotiators to perform well for their clients during negotiations over charges and sentencing, see Douglas Maynard, "Narratives and Narrative Structure in Plea Bargaining," 23 Law \& Soc'y Rev. 449 (1988).

7. William O'Barr \& Boman K. Atkins, "Women's Language or Powerless Language," in S. McConell-Ginet, R. Borker, \& N. Furman, eds., Women and Language in Literature and Sociery (New York: Praeger, 1980) ("O'Barr \& Atkins, "Women's Language" ").

8. John M. Conley \& William M. O’Barr, "Rules versus Relationships in Small Claims Narratives," in Allen Grimshaw, ed., Conflict Talk (Cambridge: Cambridge University Press, 1990) ("Conley \& O'Barr, 'Rules versus Relationships" "); id, Rules versus Relationships: The Ethnography of Legal Discourse (Chicago: University of Chicago Press, 1990) ("Conley \& O'Barr, Rules versus Relationships").

9. James L. Kinneavy, A Theory of Discourse (New York: Norton, 1971). 
Beyond these descriptive beginnings, our understanding of the perceptual effects of language style in legal settings is limited in at least six ways. First is the problematic nature of the generalizability of previous speech style experiments across different disputing forums. Work on speech styles and disputing has thus far focused on legal contexts (whether created in the laboratory or observed in situ). Unknown is whether speech style (or discourse) findings generalize across different disputing decision makers, such as mediators, or whether the effects obtained in previous experiments are bound to the institutional contexts from which subjects are drawn. Because of the role that social context plays in shaping perceptions and evaluations of language, this constitutes a significant shortcoming in our knowledge of law and language.

Second, and related to this first shortcoming, explanations for the effects observed in previous experiments have been undertheorized, either remaining at the descriptive level as in many ethnographic studies or relying on ad hoc social psychological theorizing. Less systematic attention has been paid to the difference that the primary context of interest-the court-might make for speech style effects. For example, O'Barr argues that personal evaluations of speech may vary by similarities in expectations between judges and jurors, on the one hand, and witnesses and attorneys, on the other hand, regarding assertiveness and dominance in courtroom interaction. ${ }^{10}$ Judicial evaluations of powerless speech may be quite negative, for example, when judges hold strong expectations that testimony will and should be delivered in a powerful style. Bradac and Mulac contend that what legal decision makers think are the intentions of witnesses may also affect speech evaluations. ${ }^{11}$ Conley and O'Barr use their ethnographic data on legal discourse to contend that judges' orientations toward the law may vary, which may lead to different kinds of courtroom interactions, ranging from harmonious cooperation to complete discord and frustration for all involved. ${ }^{12}$ Despite this suggestive foundation, what is needed are theoretical constructs that ground these explanations in the linguistic expectations inherent in such relevant social contexts as the court or alternative dispute resolution forums where disputants press their claims.

Third, experiments on law and language have only been conducted with undergraduate or graduate student subjects acting as "legal decision makers." 13 Studies involving practicing legal decision makers have been

10. O'Barr, Linguistic Evidence 78.

11. James J. Bradac \& Anthony Mulac, "A Molecular View of Powerful and Powerless Speech Styles: Attributional Consequences of Specific Language Features and Communicator Intentions," 51 Comm. Monographs 307 (1984).

12. Conley \& O'Barr, Rules versus Relationships 85-112.

13. See, e.g., the synthesis of speech style affects research in $O^{\prime} B a r r$, Linguistic Evidence 61-91. See also James J. Bradac, Michael R. Hemphill, \& Charles H. Tardy, "Language 
confined to ethnographies and discourse analyses from which language effects on legal processes have been inferred or suggested. ${ }^{14}$ Thus, speech style experiments may generalize to lay populations (at least including ages 18-22) from which jurors are drawn but may pose serious threats to validity for populations of such professional legal decision makers as judges, magistrates, and commissioners. ${ }^{15}$ This is especially important because judges settle most of the cases that reach trial; jury trials are relatively rare in the legal system. ${ }^{16}$

Fourth, because of the obvious importance of credibility to the efficacy of testimony, several experimenters have investigated the relationship between speech style and witness credibility. In these studies credibility has been analyzed as a composite of several personal characteristics: competence, attractiveness, trustworthiness, and convincingness. The experiments have yielded inconsistent findings. Some researchers have found that subjects perceived powerless speakers to be less competent, attractive, trustworthy, and convincing than powerful speakers. ${ }^{17}$ Conversely, other researchers have found that powerless speakers were perceived as more competent but not more attractive than powerful speakers. ${ }^{18}$ Other re-

Style on Trial: Effects of Powerful and Powerless Speech upon Judgments of Victims and Villains," 45 W.J. Speech Comm. 327 (1981); Bradac \& Mulac, 51 Comm. Monographs 307; Lawrence A. Hosman \& John W. Wright II, "The Effects of Hedges and Hesitations on Impression Formation in a Simulated Courtroom Context," 51 W.J. Speech Comm. 173 (1987); Lawrence A. Hosman, "The Evaluative Consequences of Hedges, Hesitations, and Intensifiers: Powerful and Powerless Speech Styles," 15 Hum. Comm. Res. 383 (1989).

14. See, e.g., John M. Conley \& William M. O'Barr, "Fundamentals of Jurisprudence: An Ethnography of Judicial Decision Making in Informal Courts," 66 N.C.L. Rev. 467 (1987); Maynard, 22 Law \& Soc'y Rev. 449; Conley \& O'Barr, "Rules versus Relationships"; id., Rules versus Relationships.

15. The use of the "college sophomore" in experimental research as representative of lay populations has provoked debate in the social sciences for nearly 50 years. Although there is not a clear rule-of-thumb for using college students in experimental research, suffice to say that many scholars question the external validity of their use. See, e.g., Quinn McNemar, "Opinion-Attitude Methodology," 43 Psychological Bul. 289 (1946); Robert Rosenthal \& Ralph L. Rosnow, Essentials of Behavioral Research: Methods and Data Analysis (New York: McGraw-Hill, 1984); William Oakes, "External Validity and the Use of Real People as Subjects," 27 Am. Psychologist 959 (1972); Michael E. Gordon, L. Allen Slade, \& Neal Schmitt, "The Science of Sophomore Revisited: From Conjecture to Empiricism," 11 Acad. Mgmt. Rev. 191 (1986). Alternatively, John P. Campbell, "Labs, Fields and Straw Issues," in Edwin A. Locke, ed., Generalizing from Laboratory to Field Settings 276 (Lexington, MA: Lexington Books, 1986), questions the validity of not considering that "college students really are people" and can be used with appropriate techniques to perform useful social science research. But see Jerald Greenberg, "The College Sophomore as Guinea Pig: Setting the Record Straight," 12 Acad. Mgmt. Rev. 157 (1987).

16. Steven Vago, Law and Society 80-81 (Englewood Cliffs, N.J.: Prentice-Hall, 1981).

17. Bonnie Erickson, E. Allan Lind, Bruce C. Johnson, \& William M. O'Barr, "Speech Style and Impression Formation in a Court Serting: The Effects of Powerful and Powerless Speech," 14 J. Experimental Soc. Psychology 266 (1978); E. Allan Lind \& William M. O'Barr, "The Social Significance of Speech in the Courtroom," in Howard Giles \& Robert St. Claire, eds., Language and Social Psychology (College Park: University of Maryland Press, 1979).

18. Bradac er al., 45 W.J. Speech Comm. 327. 
searchers have found an inverse relationship between powerless speech and the competency of testimony. ${ }^{19}$ Still other researchers have found the component parts of powerless speech (hedges, tag questions, intensifiers, etc.) vary in their production of speaker perceptions. ${ }^{20}$ By contrast, the effects of discourse spoken in court on credibility or the interaction effects between speech styles and discourse on perceptions of speaker credibility in court have not been studied. Thus, the relative effectiveness of these communication styles for pressing one's claims in court remains unclear.

Fifth, we have little empirical knowledge about the perceptions of social status that decision makers in legal contexts form about litigants and witnesses based solely on their speech styles or discourse. Experimental researchers have largely focused on perceptions of the personal traits of speakers based on their speech styles-in particular, their personal credibility. This shortcoming is particularly salient because of the importance of information about disputant social status for case dispositions ${ }^{21}$ and the theoretical nature of the construct of powerless and powerful speech.

Lakoff originally identified the linguistic elements that comprise powerless speech as "women's language" because she believed the style to be archetypal of oral communication by women. ${ }^{22}$ Subsequent ethnographic investigations by O'Barr and Atkins found that women's language appeared to be associated more with social status, particularly class and educational level, than with gender. ${ }^{23}$ Even if demographic studies do relate particular speech styles and discourse types with speakers' class or educational backgrounds, from previous research it is unclear whether speech style actually insinuates social information into dispute processing.

Sixth, powerless speech styles have been associated with two other crucial perceptions in court: which disputant is to blame for a dispute (when it cannot be clearly inferred from the content of testimony) and the seriousness of the dispute. Previous research has again yielded inconsistent results. Bradac, Hemphill, and Tardy, for example, found that undergraduate students related a disputant's powerless speech to increased blame for a dispute in one study but not another. They also found that when disputants spoke powerfully, their dispute was likely to be perceived as more serious than when they spoke powerlessly. These findings also resulted solely from experiments with undergraduate subjects in mock courtroom settings, thus relating to the concerns noted above. ${ }^{24}$

19. Katherine Warfel, "Gender Schemes and the Perceptions of Speech Style," 51 Comm. Monographs 253 (1984).

20. Bradac \& Mulac, 51 Comm. Monographs 307; Hosman \& Wright, 51 W.J. Speech Comm. 173; Hosman, 15 Hum. Comm. Res. 383.

21. Donald Black, The Behavior of Law (New York: Academic Press, 1976) ("Black, Behavior of Law").

22. Robin Lakoff, Language and a Woman's Place (New York: Harper \& Row, 1975).

23. O'Barr \& Atkins, "Women's Language" (cited in note 7).

24. Bradac, Hemphill, \& Tardy, 45 W.J. Speech Comm. 327 (cited in note 13). 
These limitations suggest three exploratory research questions we consider crucial to furthering our understanding of perceptual language effects in both legal and alternative dispute forums:

1. Does speech style affect perceptions of a disputant's credibility, social status, testimony quality, blameworthiness, and dispute seriousness by undergraduates, judges, and mediators?

A second question relates to rule versus relational discourse:

2. Does discourse affect perceptions of a disputant's credibility, social status, testimony quality, blameworthiness, and dispute seriousness by undergraduates, judges, and mediators?

A third research question concerns the interaction effects of speech style and discourse type. That is, what difference does it make that a disputant speaks powerlessly using relationally oriented discourse or powerfully using rule-oriented discourse? Stated formally:

3. Does speech style and discourse interact to affect perceptions of a disputant's credibility, social status, testimony quality, blameworthiness, and dispute seriousness by undergraduates, judges, and mediators?

We first describe our methodology and findings. We then discuss some alternative explanations of our results, including the possibility that our findings may be explained by focusing on the institutional contexts of subjects. Finally, we raise some questions for future law and language research.

\section{METHOD}

Three studies were conducted to explore our research questions. Speech style (powerful versus powerless) and discourse (rule versus relational) formed a $2 \times 2$ repeated measures design in each of the three experiments. We opted for this design rather than a between-subjects design as in previous experiments on law and language because of the limited numbers of sitting judges and practicing mediators available for the research. ${ }^{25}$

25. For examples of between-subject designs in law and language experimentation, see Bradac et al., 45 W.J. Speech Comm. 327; Bradac \& Mulac, 51 Comm. Monographs 307; Hosman \& Wright, 51 W.J. Speech Comm. 173; Hosman, 15 Hum. Comm. Res. 383 (all cited in note 13). Although there are enough undergraduate students in Arizona's state university system to use a between-subjects design (as typically used for the convenience samples of undergraduates in previous experimental research in this area), there are not enough sitting judges or practicing mediators in the state to a priori choose such a design. Given the limited numbers in these subject pools and the difficulty in gaining access to them, to ensure adequate statistical power, the best research design is a repeated measures, within-subjects design. As subsequent order-by-manipulation effect analyses demonstrated, nothing was lost with this design. 


\section{Subjects}

Seventy-one undergraduate students at the University of Arizona (41 female and 30 male) participated in one experiment to obtain extra credit in a course. Forty-two superior court judges ( 35 male and 7 female) participated in a second experiment at an educational conference for judges in return for a later presentation by the authors on law and language. Thirtythree community mediators ( 15 male and 18 female) participated in a third study at a monthly continuing education training session in return for a later presentation by the authors on disputing and language. All subjects participated voluntarily.

\section{Testimony}

We selected an excerpt from testimony collected by Conley and O'Barr in their ethnography of a small claims court because of its adaptability to either court or mediation contexts. The stimulus case involved a woman who unsuccessfully sued her next-door neighbor to recover money she paid to have trees and shrubs trimmed that had grown from the defendant's to the plaintiff's side of their adjoining property line. We modified this case so that both disputants were male and the dispute focused on who should pay for the removal of the trees and house repairs caused by trees rubbing against the plaintiff's roof. ${ }^{26}$

Our excerpted segment could be read in six to eight minutes and made sense on its own terms with the background information we provided to the subjects. We chose to use written stimuli rather than oral stimuli because of earlier findings that written transcripts were sufficient to produce differences in perceptions of witnesses' language style and did not differ significantly from the perceptions produced by audio stimuli. ${ }^{27}$ The physical conditions under which the studies were conducted with judges and mediators (described below) also necessitated the use of written transcripts. We thus sacrificed the naturalness of audio or video stimuli but gained the control of other sources of variation, such as nonverbal communication or physical appearance.

We edited the excerpt to yield four stimuli with different mixes of our two independent variables: powerful-rule, powerful-relational, powerless-rule, and powerless-relational. Powerless speech was operationalized in the man-

26. Conley \& O’Barr, "Rules versus Relationships" at 180-81 (cited in note 8).

27. Erickson et al., 14 J. Experimental Soc. Psychology at 277 (cited in note 17); but see Larry Vinson \& Craig Johnson, "The Use of Written Transcripts in Powerful and Powerless Language Research," 2 Comm. Rep. 16 (1989). 
ner suggested by previous research. ${ }^{28}$ Because discourse has nor previously been manipulated, we followed Conley and O'Barr's conceptual definitions on rule-oriented and relational-oriented discourse. ${ }^{29}$ The two types of discourse essentially varied in the amount of references to the actual facts of the case versus the relationships involved. The powerless-rule and powerful-rule testimonies ranged from 150 to 180 words arranged in responses to the questions of either a judge (in the court context) or a mediator (in the mediation context). The powerless-relational and powerfulrelational testimonies ranged from 300 to 330 words again arranged in responses to a judge's or mediator's questions. ${ }^{30}$ The names, places, and certain legal technicalities were omitted in the stimuli. The plaintiff was identified as Mr. Rawls and the defendant as Mr. Bennet. In our transcripts, only Mr. Rawls spoke. Examples of some differences between the four stimuli appear in the following passages taken from the actual stimuli used for judges and undergraduates in which the case was placed in court context.

\section{Powerless-Relational}

Q: Mr. Rawls, you're alleging that these trees and the shrubs and apparently the hedge were removed. When did this happen?

A: Oh, well now that happened this year, right? At uh ...

$\mathrm{Q}:$ How did it happen?

A: Ah, now three years ago Mr. Bennet moved back to his house, I guess, after having been away for some time. You see, all my neighbors took care of that hedge, you know. They, um, never let me trim it. Let's see, I would talk with Mr. Bennet about . . . uh . . . lots of things. He was kinda of friendly ...

Q: How did the hedge get removed?

28. See, e.g., Erickson et al., 14 J. Experimental Soc. Psychology at 266; Bradac et al., 45 W.J. Speech Comm. 327; Bradac \& Mulac, 51 Comm. Monographs 307.

29. Conley \& O'Barr, "Rules versus Relationships" at 179-82 (cited in note 8).

30. To be sure, the rule- and relational-oriented messages varied in length as well as content. However, such variations are consistent with the conceptual definitions Conley and O'Barr offered:

It [a rule-oriented account] does nor deal with motivations, feelings, or reasons why the contact should never have existed. Nor does it beg for understanding of contract violations on the basis of greater and more pressing problems than the need to meet contractual obligations. By contrast, relational accounts are filled with background details that are presumably relevant to the litigant, but not necessarily the court, and emphasize the complex web of relationships between the litigants rather than legal rules or formal contracts.

O'Barr \& Conley, "Rules versus Relationships" at 179. 
A: Well um, uh, Mr. Bennet asked me, I suppose, not to trim the trees growing through the hedge when he moved back, ok? He kind of said, "The church is going to pay to have them taken out, because my wife wants to put a fence and plant roses there." I agreed with him, you know, and believe, uh, I offered money for tools, ok, to help remove the stumps beneath the hedge, you know? Nothing really was done for sort of about three years after our conversation. The trees grew up as you can see in the picture, haven't they? They're big now, aren't they? So, I, uh, hired a fellow, right, from the Milehigh Tree Service, that's right isn't it, to remove them for somewhere around $\$ 275$ or so-check the figures, ok? ...

\section{Powerless-Rule}

Q: Mr. Rawls, you're alleging that these trees, the shrubs, and apparently the hedge were removed. When did this happen?

A: Um, this year.

$Q:$ How did it happen? How did the hedge get removed?

A: And, well, Mr. Bennet asked me not to trim the trees growing from his property through the hedge. Uh, let's see, He said, um, "The church is going to take them out, because my wife wants to put a fence and plant roses on the other side." I, uh, offered money to him to buy tools if needed any, you know? That's what happened I think? You see, three years passed, uh, that's it, and Mr. Bennet nor the church removed them. So, I hired the Milehigh Tree Service, that's right isn't it, to remove them for somewhere around $\$ 275$ or socheck the figures, ok? ...

\section{Powerful-Relational}

Q: Mr. Rawls, You're alleging that these trees, the shrubs, and apparently the hedge were removed. When did this happen?

A: It happened this year.

Q: How did it happen?

A: Three years ago Mr. Bennet moved back to his house after having been away from some time. For years all my neighbors took care of that hedge. The never let me trim it. I would talk with Mr. Bennet about ...

Q: How did the hedge get removed? 
A: Mr. Bennet asked me not to trim the trees growing through the hedge when he moved back. He said, "The church is going to pay to have them taken out, because my wife wants to put a fence and plant roses there." I agreed with him, and offered money for tools to help remove the stumps beneath the hedge. Nothing was done for three years after our conversation. The trees grew up as you can see in the picture. They're quite large now. I hired the Milehigh Tree Service to remove them for $\$ 275 \ldots$

\section{Powerful-Rule}

Q: Mr. Rawls, you're alleging that these trees, the shrubs, and apparently the hedge were removed. When did this happen?

A: In July of this year.

$\mathrm{Q}:$ How did it happen? How did the hedge get removed?

A: Mr. Bennet asked me not to trim the trees growing from his property through the hedge. He said, "The church is going to take them out, because my wife wants to put a fence a plant roses on the other side." I offered money to him to buy tools if he needed any. Three years passed and Mr. Bennet nor the church removed them. I hired the Milehigh Tree Service to remove them for $\$ 275 \ldots$

\section{Procedures}

In study 1 , undergraduate subjects at a large state university reported to a study called "Legal Experiment" and were told that the purpose of the study was to investigate people's reactions to trial testimony, that they would shortly read some segments of testimony from an actual small claims court trial, and about the details of the case. Subjects were also told that they would only be hearing the plaintiff's (Mr. Rawls) testimony, that there were no lawyers in the case as it was in small claims court, that the person asking questions was a small claims court judge, and that $\mathrm{Mr}$. Rawls's testimony in each excerpt would describe aspects of the case.

After listening to this information, each subject received a packet containing four excerpts (reflecting the four conditions of the experiment) with questionnaires attached to them asking for their reactions to the testimony they had just read. The ordering of the testimony was varied in a design utilizing systematic counterbalancing and randomization. ${ }^{31}$ Each transcript (treatment) appeared first an equal number of times in each

31. Geoffrey Keppel, Design and Analysis: A Researcher's Handbook 372-77 (Englewood Cliffs, N.J.: Prentice Hall, 1982). 
packet within the three subject groups and all other transcripts were randomly ordered following the first transcript. The subjects were instructed to read the first transcript in their packet and answer the questions stapled to it based on their reaction to the attached excerpt only. The experimenter then asked subjects to place the excerpt and the questionnaire face down on their desks and await instructions to read the next transcript. The experimenter waited until all subjects had finished each set of questionnaires before telling them to proceed. These procedures were repeated until all four excerpts had been completed by each subject.

Prior to study 2, adjudicator subjects received a notice in their preconference materials explaining that they would be subjects in an experiment focused on their reactions to excerpts from trial testimony. After the experiment, the materials further explained that the experimenters would present a half-hour lecture on law and language, after which the adjudicators could ask questions about the experiment or the lecture. At the conference, a moderator introduced the first author to adjudicator subjects seated in a large courtroom on folding chairs and gallery benches. The first author reiterated the explanations and order of events outlined in the preconference materials received by subjects. The case stimuli were identical to those used in study 1 . Study 2 was administered in the same way as study 1.

Prior to study 3, community mediator subjects in a large western city received a notice in their community mediation monthly newsletter explaining that at their next "in-service" monthly training session they would be subjects in a study focused on their reactions to excerpts from a mediation. The materials further explained that after the study, the investigators would present a half-hour lecture on language and disputing as well as answer questions about the study.

At the training session, a moderator introduced the first author to mediator subjects seated in a large meeting room. The first author reiterated the explanations and order of events outlined in their preconference materials received by subjects. The case stimuli were identical to those used in studies 1 and 2 except that the context of the case was recast as a mediation (such small claims mediations are common at the community mediation center from which subjects were drawn) and the questioner was recast as a mediator. One word was changed in the questions asked of Mr. Rawls: The mediators' stimuli began with, "Mr. Rawls, you're saying that ..." rather than in studies 1 and 2, in which a judge asked "Mr. Rawls, you're alleging that. ..." Study 3 was administered in the same way as studies 1 and 2 . 


\section{Dependent Measures}

The dependent measures in the studies consisted of subjects' impressions of the speaking disputant (Mr. Rawls) and the dispure itself. Participants rated Rawls's credibility on five subscales, each composed of four seven-interval semantic differential scales to measure Rawls's competence, character, sociability, composure, and extroversion. ${ }^{32}$ Coefficient alpha reliabilities for the five subscales were $.90, .78, .77, .91$, and .75 , respectively. Participants rated Rawls's testimony quality on ten seven-point semanticdifferential scales as well. A composite index was computed from the tenitem scales. Coefficient alpha reliability for the testimony quality index was .82. Participants also rated disputant social characteristics socioeconomic class, educational attainment, and social intimacy on nine seven-point Likert-Type agreement scales, three for each variable. A composite index was computed from the three scales measuring each variable. Coefficient alpha reliabilities for the three social characteristic variables were $.65, .68$, and .73 , respectively. Finally, participants indicated the extent to which they felt Rawls was to blame (alpha $=.58$ ) in the dispute on two sevenpoint Likert-type agreement scales and their perceptions of the seriousness of the dispute on a single agreement scale. ${ }^{33}$

\section{Analysis}

A protected $F$ approach was used to analyze the data in each study. Initially, a repeated measures multivariate analysis of variance (MANOVA) was conducted to examine the effects of the independent variables on the dependent measures set. MANOVA analyses were also performed to assess order-by-manipulation effects of the four messages on each subject. These analyses yielded small $F$-scores, none of which approached significance. As a result, the within-subjects analysis was pursued. Second, significant MANOVA effects were probed with univariate analysis of variance (ANOVA). The analysis of nonsignificant MANOVA effects was terminated. Finally, significant ANOVA interaction effects were probed using the Newman-Keuls procedure, while the analysis of nonsignificant effects was terminated. This procedure maintains the experiment-wise alpha error rate near the specified .05 level by protecting later stages of the analysis against error with the significance of prior tests. ${ }^{34}$

32. James C. McCroskey, "Scales for the Measurement of Ethos," 33 Speech Monographs 65 (1966).

33. Larry A. Hembroff, "The Seriousness of Acts and Social Contexts: A Test of Black's Theory of the Behavior of Law," 93 Am. J. Soc. 322 (1987).

34. Robert Rosenthal \& Ralph L. Rosnow, Essentials of Behavioral Research: Methods and Data Aralysis (New York: McGraw-Hill, 1984). 


\section{RESULTS}

\section{Undergraduate Perceptions in Study 1}

Table 1 presents undergraduate mean perceptions of the disputant and the dispute as they varied by speech style, discourse, and the interaction of speech style and discourse. MANOVA indicated that disputant speech style significantly influenced undergraduate perceptions of the speaking disputant and the disputant (Lambda $=.32, F(11,270)=52.71$, $p<.001)$. Subsequent univariate analyses revealed that undergraduates perceived the powerfully speaking disputant to be more competent $(F(1,280)=428.60, p<.001)$, of higher character $(F(1,280)=162.85, p$ $<.001)$, more sociable $(F(1,280)=67.28, p<.001)$, more composed $(F(1,280)=298.49, p<.001)$, more extroverted $(F(1,280)=137.23, p$ $<.001)$, giving higher quality testimony $(F(1,280)=103.40, p<.001)$, from a higher socioeconomic class $(F(1,280)=489.07, p<.001)$, better educated $(F(1,280)=253.64, p<.001)$, slightly more socially intimate with the other disputant $(F(1,280)=9.83, p<.01)$, and less to blame for the dispute $(F(1,280)=71.73, p<.001)$ than the powerlessly speaking disputant. Although a significant multivariate effect for discourse was found $($ Lambda $=.92, F(11,270)=2.13, p<.05)$, only a single univariate effect emerged: Subjects perceived Rawls to be more composed $(F(1,280)$ $=7.46, p<.01$ ) when he spoke in a rule-oriented discourse than when he spoke in the relationally oriented discourse. Significant interaction effects were not found among the undergraduate subjects (Lambda $=.98$, $F(11,270)<1.00, p>.05)$.

\section{Judges' Perceptions in Study 2}

Like the undergraduate sample, speech style also affected judges' perceptions of the speaking disputant and the dispute (Lambda $=.52$, $F(11,150)=12.51, p<.001$ ) (as indicated in table 2 ). When Rawls gave testimony in the powerful style, judges rated him more competent $(F(1,160)=56.20, p<.001)$, of higher character $(F(1,150)=11.36, p<$ $.01)$, more sociable $(F(1,160)=4.11, p<.05)$, more composed $(F(1,160)$ $=87.77, p<.001)$, more extroverted $(F(1,160)=29.51, p<.001)$, as delivering better testimony $(F(1,160)=25.00, p<.001)$, to be from a higher socioeconomic class $(F(1,160)=49.80, p<.001)$ better educated $(F(1,160)=77.07, p<.001)$, and less to blame for the dispute $(F(1,160)$ $=11.56, p<.01)$ than when his testimony was delivered in the powerless style. Neither discourse alone ( $\operatorname{Lambda}=.95, F(11,150)<1.00, p>.05)$ nor speech style by discourse interactions (Lambda $=.94, F(11,150)<$ $1.00, p>.05)$ affected judges' perceptions of the disputant or the dispute. 


\section{TABLE 1}

Students' Mean Perceptions of Disputant and Dispute Characteristics

\section{A. Main Effects}

\begin{tabular}{llclll}
\hline & \multicolumn{2}{c}{ Speech Style } & & \multicolumn{2}{c}{ Discourse } \\
\cline { 2 - 3 } \cline { 6 - 6 } & Powerful & Powerless & & Rule & Relational \\
\hline Competence & $5.49^{* * *}$ & 2.89 & & 4.16 & 4.23 \\
Character & $5.42^{* * *}$ & 4.06 & & 4.75 & 4.74 \\
Sociability & $4.74^{* * *}$ & 3.93 & & 4.32 & 4.35 \\
Composure & $4.95^{* * *}$ & 2.60 & & $3.97^{*}$ & 3.56 \\
Extroversion & $4.52^{* * *}$ & 3.35 & & 3.99 & 3.87 \\
Testimony quality & $4.79^{* * *}$ & 3.86 & & 4.34 & 4.30 \\
Social class & $4.13^{* * *}$ & 2.20 & & 3.19 & 3.14 \\
Education & $5.72^{* * *}$ & 3.54 & & 4.69 & 4.57 \\
Social intimacy & $3.97^{* *}$ & 3.56 & & 3.74 & 3.79 \\
Blameworthiness & $3.33^{* * *}$ & 4.31 & & 3.84 & 3.80 \\
Seriousness & 3.17 & 2.96 & & 3.06 & 3.12 \\
& & & & & \\
\hline
\end{tabular}

B. Interactions

\begin{tabular}{lcccc}
\hline & $\begin{array}{c}\text { Powerful- } \\
\text { Rule }\end{array}$ & $\begin{array}{c}\text { Powerful- } \\
\text { Relational }\end{array}$ & $\begin{array}{c}\text { Powerless- } \\
\text { Rule }\end{array}$ & $\begin{array}{c}\text { Powerless- } \\
\text { Relational }\end{array}$ \\
\hline Competence & 5.47 & 5.51 & 2.79 & 3.00 \\
Character & 5.46 & 5.39 & 4.00 & 4.11 \\
Sociability & 4.74 & 4.74 & 3.89 & 3.98 \\
Composure & 5.13 & 4.71 & 2.76 & 2.45 \\
Extroversion & 4.54 & 4.49 & 3.42 & 3.28 \\
Testimony quality & 4.81 & 4.76 & 3.86 & 3.86 \\
Social class & 4.08 & 4.18 & 2.25 & 2.15 \\
Education & 5.66 & 5.79 & 3.68 & 3.41 \\
Social intimacy & 3.94 & 4.04 & 3.56 & 3.56 \\
Blameworthiness & 3.34 & 3.31 & 4.35 & 4.27 \\
Seriousness & 3.09 & 3.25 & 2.91 & 3.00 \\
& & & & \\
\hline \multicolumn{1}{c}{${ }^{*} p<.05$} & $* * * 01$ & $* .01$ & $* * * 01$ & \\
\hline
\end{tabular}

\section{Mediators' Perceptions in Study 3}

In contrast to undergraduates and judges, table 3 indicates that neither speech style alone (Lambda $=.95, F(11,113)<1.00, p>.05)$ nor discourse (Lambda $=.94, F(11,113)<1.00, p>.05)$ affected mediators' perceptions of the disputant and the dispute. However, MANOVA revealed a significant interaction between the two language styles ( $\mathrm{Lambda}=$ $.57, F(11,113)=.57, p<.05)$. Subsequent univariate analyses indicated 
LAW AND SOCIAL INQUIRY

TABLE 2

Judges' Mean Perceptions of Disputant and Dispute Characteristics

\section{A. Main Effects}

\begin{tabular}{llclll}
\hline & \multicolumn{2}{c}{ Speech Style } & & \multicolumn{2}{c}{ Discourse } \\
\cline { 2 - 3 } \cline { 5 - 6 } \cline { 5 - 6 } & Powerful & Powerless & & Rule & Relational \\
\hline Competence & $4.71^{* * *}$ & 3.46 & & 4.11 & 4.06 \\
Character & $4.86^{* *}$ & 4.28 & & 4.50 & 4.54 \\
Sociability & $4.38^{*}$ & 4.12 & & 4.27 & 4.24 \\
Composure & $4.39^{* * *}$ & 2.85 & & 3.78 & 3.46 \\
Extroversion & $4.18^{* * *}$ & 3.41 & & 3.82 & 3.77 \\
Testimony quality & $4.46^{* * *}$ & 3.84 & & 4.18 & 4.11 \\
Social class & $3.75^{* * *}$ & 2.48 & & 3.10 & 3.13 \\
Education & $4.55^{* * *}$ & 2.92 & & 3.79 & 3.68 \\
Social intimacy & 4.29 & 4.09 & & 4.11 & 4.26 \\
Blameworthiness & $3.76^{* *}$ & 4.34 & & 4.06 & 4.04 \\
Seriousness & 3.20 & 2.94 & & 3.02 & 3.11 \\
\hline
\end{tabular}

B. Interactions

\begin{tabular}{lcccc}
\hline & $\begin{array}{c}\text { Powerful- } \\
\text { Rule }\end{array}$ & $\begin{array}{c}\text { Powerful- } \\
\text { Relational }\end{array}$ & $\begin{array}{c}\text { Powerless- } \\
\text { Rule }\end{array}$ & $\begin{array}{c}\text { Powerless- } \\
\text { Relational }\end{array}$ \\
\hline Competence & 4.77 & 4.64 & 3.43 & 3.49 \\
Character & 4.87 & 4.85 & 4.33 & 4.24 \\
Sociability & 4.50 & 4.36 & 4.12 & 4.12 \\
Composure & 4.29 & 4.27 & 3.03 & 2.66 \\
Extroversion & 4.45 & 4.07 & 3.34 & 3.48 \\
Testimony quality & 4.76 & 4.47 & 3.90 & 3.77 \\
Social class & 3.76 & 3.73 & 2.41 & 2.54 \\
Education & 4.54 & 4.56 & 3.02 & 2.82 \\
Social intimacy & 4.25 & 4.34 & 3.98 & 4.20 \\
Blameworthiness & 3.82 & 3.70 & 4.30 & 4.37 \\
Seriousness & 3.24 & 3.15 & 2.80 & 3.07 \\
& & & & \\
\hline \multirow{2}{*}{${ }^{*} p<.05$} & $* * p<.01$ & $* * * p<.001$ & & \\
\hline
\end{tabular}

the speech by discourse interaction affected mediators' perceptions of Rawls's competence $(F(1,123)=38.76, p<.001)$, composure $(F(1,123)$ $=45.41, p<.001)$, extroversion $(F(1,123)=24.22, p<.001)$, socioeconomic class $(F(1,123)=16.50, p<.001)$, educational attainment $(F(1,123)=54.79, p<.001)$, and blameworthiness for the dispute $(F(1,123)=5.27, p<.05)$. In each case, Rawls received more favorable ratings in the powerful-rule and powerless-rational conditions than in other conditions. 
TABLE 3

\section{Mediators' Mean Perceptions of Disputant and Dispute}

Characteristics

\section{A. Main Effects}

\begin{tabular}{llcccc}
\hline & \multicolumn{2}{c}{ Speech Style } & & \multicolumn{2}{c}{ Discourse } \\
\cline { 6 - 6 } \cline { 5 - 6 } & Powerful & Powerless & & Rule & Relational \\
\hline Competence & 4.27 & 4.36 & & 4.35 & 4.27 \\
Character & 4.52 & 4.56 & & 4.50 & 4.58 \\
Sociability & 4.18 & 4.21 & & 4.15 & 4.24 \\
Composure & 3.68 & 3.92 & & 3.76 & 3.85 \\
Extroversion & 4.05 & 4.03 & & 4.07 & 4.01 \\
Testimony quality & 4.31 & 4.49 & & 4.32 & 4.48 \\
Social class & 3.54 & 3.58 & & 3.61 & 3.51 \\
Education & 4.13 & 4.17 & & 4.23 & 4.07 \\
Social intimacy & 4.02 & 3.98 & & 3.87 & 4.14 \\
Blameworthiness & 3.81 & 3.80 & & 3.85 & 3.76 \\
Seriousness & 4.31 & 4.30 & & 4.31 & 4.31 \\
& & & & & \\
\hline
\end{tabular}

B. Interactions

\begin{tabular}{llccc}
\hline & $\begin{array}{c}\text { Powerful- } \\
\text { Rule }\end{array}$ & $\begin{array}{c}\text { Powerful } \\
\text { Relational }\end{array}$ & $\begin{array}{c}\text { Powerless- } \\
\text { Rule }\end{array}$ & $\begin{array}{c}\text { Powerless- } \\
\text { Relational }\end{array}$ \\
\hline Competence & $4.79^{* * *}$ & 3.64 & $3.92^{* * *}$ & 4.84 \\
Character & 4.55 & 4.50 & 4.46 & 4.66 \\
Sociability & 4.20 & 4.15 & 4.10 & 4.32 \\
Composure & $4.16^{* * *}$ & 3.21 & $3.37^{* * *}$ & 4.54 \\
Extroversion & $4.44^{* * *}$ & 3.67 & $3.71^{* * *}$ & 4.37 \\
Testimony quality & 4.33 & 4.29 & 4.68 & 4.32 \\
Social class & $3.92^{* * *}$ & 3.16 & $3.30^{* * *}$ & 3.88 \\
Education & $4.81^{* * *}$ & 3.45 & $3.67^{* * *}$ & 4.73 \\
Social intimacy & 3.94 & 4.11 & 3.80 & 4.17 \\
Blameworthiness & $3.72^{*}$ & 3.91 & $3.98^{* * *}$ & 3.60 \\
Seriousness & 4.31 & 4.31 & 4.30 & 4.30 \\
\hline \multicolumn{1}{c}{$* 0$}
\end{tabular}

\section{Individual-Level Analyses}

Individual subject characteristics (gender, age, and education) were not found to significantly affect perceptions of the disputant and dispute, either alone or as they interacted with speech style, discourse, and the three subject groups (undergraduates, judges, and mediators; overall multivariate $F(22,1106)<1.00, p>.05)$. 


\section{DISCUSSION}

In our studies we found that for undergraduates and judges testimony presented in powerful and powerless speech styles elicited somewhat similar perceptions of the social identity of the speaker. Undergraduate subjects perceived disputants who spoke powerlessly as being less credible, from a lower socioeconomic class, less educated, slightly more socially intimate with their adversaries, and more to blame than powerful speaking disputants. Speech style also affected judges' perceptions of the disputant in roughly the same way but more weakly. The story is quite different for mediators. The results of our experiment with mediators indicated that speech style had little effect on their perceptions of the disputant.

In contrast to the speech style effects, we found that the discourse in which a disputant engages had almost no effect on the perceptions of a disputant. Interestingly, only mediators were affected by the interaction of speech style and discourse so that perceptions of the powerful-rule and powerless-relational combinations significantly differed from the other two speech discourse combinations. Undergraduates' and judges' perceptions were not affected by these interactions. ${ }^{35}$

First, our findings speak to the appropriateness of using undergraduates in law and language experiments. Although the findings of our studies suggest that undergraduates have similar, albeit stronger, perceptions of witnesses based on their speech as those of practicing judges, we caution against inferring too much from these results. What our studies cannot answer is how similar perceptions of witnesses inferred from language enters into legal decision-making processes. One could plausibly argue that judges, for example, with their considerably more education, experience, and age than undergraduates, weigh these factors differently in decisionmaking processes in court than students in an experimental situation. Thus, we do not pretend to have unraveled the thorny problem of the use of student versus expert subjects in previous law and language experiments but only flag the issue for further study.

Second, variation in perceptions across the three subject pools raises the issue of potential explanations of these effects. Explanations based on methodological fallacies or individual-level variables (especially age, gender, and occupation) seem implausible given our experimental procedures and the lack of individual-level effects. Similarly, an explanation based on the self-selection of the subjects into the three institutions rests on very

35. Interestingly, Conley \& O'Barr, Rules versus Relationships 59-81 (cited in note 8), argue that rule-relational discourse may ultimately tell us more about witnesses' and litigants' perceptions of the legal system than about decision makers' perceptions of witnesses and litigants. Our arguments below concerning the lack of discourse effects as well as the interaction effects on mediators of style and discourse should be viewed as a complementary explanation to that offered by Conley and O'Barr. 
strong and unrealistic assumptions about the kinds of students who attend public universities as well as the kinds of people who become judges and mediators.

A more plausible explanation might be found in the differences in the social contexts, in particular the social institutions, in which each of the subject pools is embedded. Each institution from which the subjects were drawn can be regarded as a cultural "speech community" 36 containing delimited standards and patterns of language use to which institutional members are exposed daily. Such exposure creates social expectations in the members of speech communities about appropriate and inappropriate language usage and the social identifies of those who violate social expectations. Specifically, it has been argued that language which is inappropriate negatively violates social expectations through its unconventionality and is likely to be evaluated negatively. ${ }^{37}$ Each institution from which subjects were drawn in the present investigation has particular mixes of standards and conventional patterns of language usage that create particular social expectations.

Students find themselves in an institution with a speech community containing powerful styles of speech that often occur in formal (e.g., lectures by professors, presentations by colleagues) and informal situations (e.g., intellectual discussions, teacher-student conferences). The academy is also an institution in which the "literate" standards for communication are well established. Moreover, the vast majority of the subjects for this research were drawn from middle-class backgrounds and secondary educations with similar kinds of communication standards. Superior court judges are also embedded in a speech community in which most litigants and witnesses, unlike those in lower courts, may be better schooled in the art of giving testimony and may speak relatively powerfully. ${ }^{38}$ At the same time, superior courts are also contexts in which the "knowledge system" 39 is well established in regards to language, also favoring a literate form. ${ }^{40}$

The community mediators in this study, unlike students or judges, process cases in an institution that handles disputants from a wider variety of backgrounds who speak both powerfully and powerlessly. In this situation, the standards of language may also be associated with strong prescrip-

36. Dell Hymes, "Models of the Interaction of Language and Social Life," in Joseph J. Gumperz \& Dell Hymes, eds., Directions in Sociolinguistics: The Ethnography of Communication (New York: Holt, Rinehart, \& Winston, 1972).

37. Michael Burgoon \& Gerald R. Miller, "An Expectancy Interpretation of Language and Persuasion," in Howard Giles \& Robert St. Claire, eds., The Social and Psychological Contexts of Language (London: Erlbaum, 1985); but see Black, Behavior of Law at 82 (cited in note 21).

38. Conley \& O'Barr, Rules versus Relationships.

39. Andrew Abbot, The System of the Professions: An Essay on the Division of Expert Labor (Chicago: University of Chicago Press, 1988).

40. Conley \& O'Barr, Rules versus Relationships. 
tive norms about mediator neutrality resulting in mediators being taught to take a "detached stance" from clients. ${ }^{41}$ In community mediation centers in general, as well as in the center from which mediator subjects were drawn for our research, mediator neutrality is continually reinforced through evaluation and selection of practitioners as "core mediators." As Harrington and Merry argue, "Mediators who are quick to judge tend to be less highly regarded" than those who do not. ${ }^{42}$ One would expect, therefore, that mediators might manifest a reluctance to infer personal and social characteristics of disputants based on speech style.

In this light, then, it is not surprising that students and judges would have similar perceptions of powerlessly and powerfully speaking disputants given the similar speech standards and patterns concerning communication in the courtroom and classroom. The weakened effects of speech style among judges, however, may occur because the variation in the speech patterns to which they are routinely exposed is greater and because the fit between standards favoring powerful speech are not as completely reinforced by the patterns of speech they routinely deal with in court. Following the same logic, only mediators may be neutral in their evaluation of speech style in part because of the irregular distribution of speech styles they experience during mediations and because of continual reinforcement to not judge disputants.

Thus, our findings raise the possibility that disputants who speak powerfully in constructing their legal narratives will indeed have an advantage over their powerlessly speaking adversaries. These advantages may be especially accentuated in superior courts (the routine context of our subject judges). In lower, informal courts, where judges have orientations to their cases that are closer to those of mediators, ${ }^{43}$ their reactions may parallel the mediators' reluctance to draw inferences. One could positively construe such reluctance in that disputants who manifest powerless speech would not be perceived as less credible than their more powerfully speaking adversaries. At least linguistically, disputants begin mediation sessions on an even plane. Even so, such reluctance to draw inferences based on linguistic cues could inhibit mediators from recognizing and acting on subtle power difference cues exhibited by disputants in mediation sessions. Instead of establishing an even terrain for conducting mediation, mediators' lack of quick judgment might constrain their ability to empower disputants and could actually undermine the potential personal growth functions of mediation. ${ }^{44}$

41. Deborah M. Kolb, "To Be a Mediator: Expressive Tactics in Mediation," 41 J. Soc. Issues 11 (1985).

42. Christine Harrington \& Sally Engle Merry, "Ideological Production: The Making of Community Mediation," 22 Law \& Soc'y Rev. 729 (1988).

43. Conley \& O'Barr, Rules versus Relationships 82-112 (cited in note 8).

44. See, e.g., Harrington \& Merry, 22 Law $\mathcal{E}$ Soc'y Rev. 715. 
Third, our analyses revealed a significant interaction between speech style and discourse among mediators. In particular, powerful-rule and powerless-relational combinations were perceived more favorably than powerful-relational and powerless-rule. This makes sense in terms of our arguments about the institutionally generated expectations across the three subject pools. Among students, there is no institutionally generated set of social expectations that would lead students to perceive relational- or rule-oriented discourse as useful to a dispute. In superior courts, one could argue that judges tend to exhibit less variation in their rule orientation. As Conley and O'Barr note, "In formal courts, where the dominant interaction is between lawyer and witness, the judge rarely speaks and generally does so only to resolve disputed points of law." 45 When a disputant delivers testimony focused on social relationships, superior court judges may consciously attempt to extract legal-rule-related information, remaining relatively uninterested in the relational content. Therefore, the interaction of discourse and speech may be irrelevant in the superior court context because it does not yield useful information beyond the social information insinuated into the case by speech style alone.

In contrast, the interaction of speech and discourse produces uniquely useful information in the mediation context, because the focus of mediation is broader, nearly always focusing both on normative violations and social relationships. ${ }^{46}$ When a dispute is cast in relational terms by a disputant speaking in relational discourse, mediators may find the interaction too striking to ignore (even in light of their training to remain detached from disputants). Thus, mediators might evaluate the speaker using powerful language unfavorably because such use suggests status and social differences between the speaker and the other principal that mediators attempt to minimize during mediation sessions. ${ }^{47}$ When a dispute is articulated in rule-oriented terms, powerful speech may be perceived as more appropriate than powerless speech for the same reasons; in effect, a mediation session may shift to more rule-oriented issues suggestive of litigation. Again, one might expect the same combination of effects in courts with third parties who slip back and forth between mediator and adjudicator roles. Although this explanation is highly speculative, the pattern of the main effects and interactions across the three subject samples supports this interpretation.

45. Conley \& O'Barr, Rules versus Relationships at 82 (cited in note 8).

46. Lon Fuller, "Mediation-Its Forms and Functions," 44 S. Cal. L. Rev. 305 (1971).

47. Susan S. Silbey \& Sally Engle Merry, "Mediator Settlement Strategies," 8 Law \& Pol'y 7 (1986). 


\section{CONCLUSION}

We began this research with some straightforward questions about the relationship between language and law. The results suggest a potentially crucial role for institutional context in determining the effects of powerful speech and discourse. A variety of questions remain. Do the effects of language vary across different social control institutions as we suggest? Or are there other contextual features that affect perceptions of disputants based on their language, among them the intentions of the speakers as understood by listeners, ${ }^{48}$ the constellation of powerless speech forms present in testimony, ${ }^{49}$ or even nonverbal cues that interact with linguistic forms ${ }^{50}$ How does the type of court (e.g., civil versus criminal or higher versus lower) and the complexity of the case affect the perceptions of disputants by legal decision makers? How does subjects' prior knowledge of disputants interact with disputant speech style to affect perceptions? Do the social identities that decision makers form about disputants with particular speech styles provide a base for case dispositions?

This last question relates to the need to move law and language research beyond the perceptual and attitudinal level to that of outcomes. Answering larger theoretical questions linking differential power and status between disputants and case outcomes ${ }^{51}$ depends in part on understanding how social power and social status are communicated in settlement institutions. That speech styles affect perceptions, that discourse alone does not, and that some combinations of speech and discourse do affect perceptions in controlled experiments merely scratch the surface of a complete understanding of power and communication in legal and extralegal disputing. Our knowledge of such processes can only be furthered by the continual dialogue between experimental and ethnographic studies of language and law. 52

48. See, e.g., Bradac \& Mulac, 51 Comm. Monographs 307 (cited in note 13).

49. See, e.g., Hosman, 15 Human Comm. Res. 383 (cited in note 13).

50. See, e.g., Judee K. Burgoon, David B. Buller, \& Wendall G. Woodall, Nonverbal Communication: The Unspoken Dialogue 424-60 (New York: Harper \& Row, 1989).

51. See, e.g., Black, Behavior of Law; Richard L. Abel, "Introduction," in Richard L. Abel, ed., The Politics of Informal Justice: The American Experience (New York: Academic Press, 1982); Laura Nader, "Disputing without the Force of Law," 88 Yale LJ. 998 (1979).

52. William O'Barr \& E. Allan Lind, "Ethnography and Experimentation: Parners in Legal Research," in Bruce D. Sales, ed., The Trial Process (New York: Plenum Press, 1981). 